\title{
КОГНИТИВНЫЕ ТЕХНОЛОГИИ ИСПОЛЬЗОВАНИЯ ПРЕЦЕДЕНТНЫХ ФЕНОМЕНОВ В РЕКЛАМНЫХ ТЕКСТАХ
}

\section{COGNITIVE TECHNOLOGIES FOR USING PRECEDENT PHENOMENA IN ADVERTISING TEXTS}

\section{Kravchenko \\ O. Kravchenko}

Summary: This paper presents an analysis of examples of the use of precedent components, culturally, pragmatically and situationally determined in advertising discourse. Based on the study of the corpus of examples, an attempt is made to detect, classify and justify technologies that integrate case text into advertising text. According to the classification criteria, three cognitive technologies are distinguished: transfer technology, image programming technology, and cognitive deformation technology.

Keywords: precedent phenomenon, advertising discourse, cognitive technologies, transfer technology, image programming technology, cognitive deformation technology.
$\mathrm{B}$ современном мире рекламные тексты, проникающие во все сферы жизни, представляют собой большой интерес для лингвистики, в том числе для лингвостилистики, функциональной стилистики, теории коммуникаций. Особое место в рекламных текстах отводится приемам отражения действительности - прецендентным феноменам, позволяющим сохранять, передавать, сравнивать и сопоставлять кодовые элементы лингвокультуры. Главной особенностью прецендентных феноменов является наличие апперцепционной базы, объединяющей языковое сознание коммуникантов.

Прецендентные тексты часто используются в рекламном дискурсе, так как реклама отражает быстро изменяющиеся события жизнедеятельности общества, а прецендентные феномены способны транслировать систему накопленных знаний [3].

В рекламном дискурсе применяется ряд технологий использования прецедентных феноменов. Нами были описаны формально-языковые технологии использования прецедентных феноменов в рекламных текстах [2], к которым относятся технология цитирования и технология квазицитирования. В настоящей работе предпринята попытка выделить и последовательно описать когнитивные технологии использования прецедентных феноменов в рекламных текстах.
Кравченко Михаил Александрович

К.филол.н., дочент, Ростовский университет путей сообщения mak@rgups.ru

Кравченко Оксана Викторовна К.филол.н., дочент, Ростовский государственный экономический университет (РИНХ) aspiranttgpi@yandex.ru

Аннотация: В данной работе представлен анализ примеров использования прецедентных компонентов, культурно, прагматически и ситуативно обусловленных в рекламном дискурсе. На основании изучения корпуса примеров предпринята попытка обнаружения, классификации и обоснования технологий, благодаря которым прецедентный текст интегрируется в рекламный текст. В соответствии с классификационными признаками выделяются три когнитивные технологии: технология переноса, технология программирования образа, технология когнитивной деформации.

Ключевые слова: прецедентный феномен, рекламный дискурс, когнитивные технологии, технология переноса, технология программирования образа, технология когнитивной деформации.

Создание рекламного текста на базе прецедентного феномена требует культурной, прагматической и ситуативной обусловленности последнего. Именно эти условия приводят к появлению готового осмысленного рекламного продукта, обладающего значительным суггестивным потенциалом [1]. Кроме того, прецедентный компонент должен интегрироваться в рекламный текст на основе специальной технологии. Выбор технологии зависит от замысла рекламиста или особенностей текста.

На основании структурных и содержательных признаков все выделенные технологии можно разделены на две категории:

1. формально-языковые технологии;

2. когнитивные технологии.

Если формально-языковые технологии выделяются на основе структурных признаков и подразделяются в зависимости от формального способа их интеграции в пространство рекламного текста, то в основе выделения когнитивных технологий лежат содержательные, смысловые критерии. Когнитивные технологии предполагают не игру с формой, с текстом, а игру со смыслами. Когнитивные технологии апеллируют к знаниям, представлениям, стереотипам реципиентов. Когнитивные технологии, условно говоря, призывают реципиента к своеобразному диалогу, заставляют его думать, «запу- 
скают» его когнитивные механизмы.

Когнитивные технологии можно разделить на три группы:
а) технологии переноса;
b) технологии программирования образа;
c) технологии когнитивной деформации.

Технология переноса основана на механизме семантического сдвига, происходящего при сопоставлении исходного текста с рекламным текстом, содержащим прецедентный феномен. Семантический сдвиг выражается в факте переноса значения лексического компонента, перешедшего из прототекста в рекламу.

Ярким примером использования технологии переноса является реклама средства от комаров «Autan». Рассматриваемый рекламный текст дословно воспроизводит известный фразеологизм «Комар носа не подточит». Значение этого оборота по данным словаря устойчивых оборотов под редакцией М.И. Степановой можно записать как «что-либо сделано хорошо, тщательно, не к чему придраться» [4]. Иными словами, значение фразеологизма не вытекает из суммы значений его лексических компонентов. В тексте рекламы происходит семантический сдвиг: значение фразеологизма в целом уступает место значению суммы его компонентов. Таким образом, технология переноса обеспечила новое прочтение известного фразеологизма. Перенос произошел от обобщенного значения к прямому.

В тексте, рекламирующем шоколадный батончик «Mars», наблюдается аналогичный семантический сдвиг. Происходит перенос от обобщенного значения фразеологического выражения к конкретным значениям компонентов выражения: «Всё будет в шоколаде».

Технология переноса может проходить не только в результате сопоставления прямых и фразеологически связанных значений. Семантический сдвиг может происходить на стыке прямого значения и глубокого, философского значения выражения, выступающего в качестве прецедентного феномена. К такого рода примерам следует отнести цикл рекламных текстов, созданных для компании «яндекс». В первом примере используется отрывок из молитвы «спаси и сохрани» в качестве рекламы Яндекс диска, обеспечивающего возможность резервного копирования информации. Таким образом, осуществляется перенос из сферы божественного, возвышенного в сферу обыденного, повседневного.

Похожий перенос происходит в случае рекламы Яндекс-парковок. Прецедентный феномен (текст «встань и иди») заимствован из Библии: «А Филипnу Ангел Господень сказал: встань и иди...». Глубинный смысл Библейских слов сталкивается с абсолютно конкретным значением выражения, описывающего удобство автомобильной парковки.

Сущность технологии программирования образа заключается в использовании когнитивной базы реципиента для создания образа рекламируемого продукта или услуги. Как правило, отправным механизмом для программирования образа служит использованное в рекламном тексте прецедентное имя. Так, благодаря использованию технологии программирования образа при создании рекламного текста о туре в Объединенные Арабские Эмираты рекламист через прецедентное имя «сказки Шахерезады» пытается задействовать воображение реципиента, представить чудеса арабского мира: «Вечная сказка Шахерезады! Мечети, дворцы, огни лодок на каналах!».

Зачастую одно прецедентное имя может спровоцировать в сознании реципиента цепочку ассоциаций. На этой основе строится реклама ресторана «Шагал». При этом мощным суггестивным потенциалом обладает сам нейм «Шагал», за которым скрывается всемирно известный художник 20 в. У реципиента «поневоле» формируется следующий образ заведения: 1) наличие национальной составляющей, в том числе в кухне (об этом «говорит» еврейское происхождение Марка Шагала (действительно ресторан позиционируется как заведение кошерной пищи); 2) ориентация на богемную публику (известные художники, как правило, составляют ядро богемы); 3) наличие элемента неординарности и экстравагантности (Марк Шагал принадлежал к числу художников не классического направления, его творчество отличалось яркостью и оригинальностью). Список компонентов формируемого образа может быть продолжен.

Использование технологии когнитивной деформации связано с намеренным разрушением сложившихся у реципиента смысловых стереотипов. В рекламном тексте это оформляется следующим образом: широко известный прецедентный феномен, обладающий мощным когнитивным потенциалом, интегрируется в текст. При этом смысл рекламного текста «полемизирует» со сложившимся стереотипом. Как правило, формально противопоставление выражено посредством отрицательной частицы «не». Примером использования технологии когнитивной деформации может служить реклама косметики «Черный жемчуг»: Красота не требует жертв. Красота требует ухода. Ниспровержение устойчивого стереотипа привлекает особое внимание реципиента, повышая тем самым суггестивный потенциал рекламного текста.

Аналогичная технология применяется в следующей рекламе косметических услуг: Хочется и не колется. Избавление от нежелательных волос. 
Когнитивная деформация может выражаться посредством трансформации структурной организации прецедентного феномена. Как правило, это происходит за счет изменения порядка слов, которое провоцирует значительные смысловые трансформации. К этому типу когнитивной деформации, в частности, можно отнести рекламу компании «Альфастрахование»: Сделаем из мухи слона (ср. исходный фразеологизм: Делать из мухи слона - сильно преувеличивать что л., придавать чему л. незначительному большое значение).

Рассмотренные примеры позволяют сделать вывод, что использование технологии переноса, технологии программирования образа и технологии когнитивной деформации апеллируют к знаниям, представлениям, стереотипам реципиентов. Когнитивные технологии за- ставляют реципиента думать, сравнивать, сопоставлять, опираясь на семиотические знания и когнитивый фон. Реципиент попадает в когнитивную ловушку, имеющиеся у него знания противоречат информации, предъявляемой в прецендентном тексте, что способствует более точной передаче оттенков смыслов при описании ситуаций, предметов, явлений. Благодаря прецендентным феноменам текст рекламы становится ярче, информативнее, выразительнее, а рекламисту легче добиться эмоционального и эстетического воздействия на потенциального покупателя.

Прецедентные феномены, изобилующие в рекламном дискурсе, остаются богатым источником для исследования в области когнитивной лингвистики и когнитивной семантики.

\section{ЛИТЕРАТУРА}

1. Караулов Ю.Н. Роль прецедентных текстов в структуре и функционировании языковой личности// Научные традиции и новые направления в преподавании русского языка и литературы. Доклады советской делегации на VI конгрессе МАПРЯЛ. - М.: Русский язык, 1986. - С. 105-126.

2. Кравченко М.А., Кравченко О.В. Формально-языковые технологии использования прецедентных феноменов в рекламных текстах //Современная наука: актуальные проблемы теории и практики. Серия «Гуманитарные науки» №8. - 2019. - с. 142-145.

3. Кривоносов А.Д. РR-текст в системе публичных коммуникаций. - Санкт-Петербург: Центр «Петербургское востоковедение», 2002. - 288 с.

4. Степанова М.И. Фразеологический словарь русского языка. - М. Виктория плюс, 2016. - 608 с.

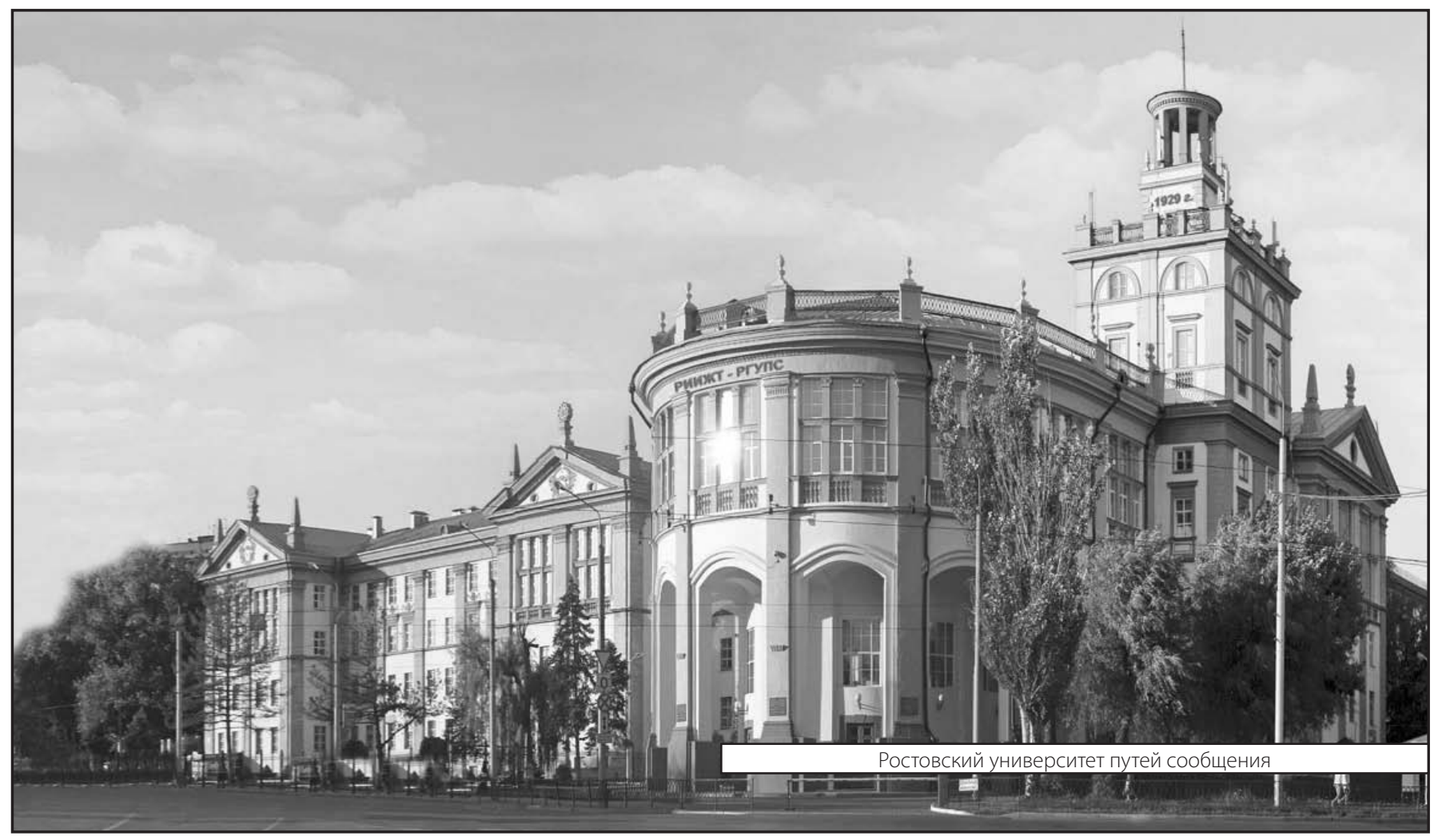

